\title{
Enhanced Enzymatic Saccharification of Mixed Sawdust Wastes: Comparison of SPORL, Dilute Acid, Formic Acid, and Ethanol Organosolv Pretreatments
}

\author{
Yuan Liang ${ }^{1}$, Yanbo Yin $^{1}$, Haifeng Zhou ${ }^{1 *}$, Yuanyu Tian ${ }^{1,2}$ \\ ${ }^{1}$ Key Laboratory of Low Carbon Energy and Chemical Engineering, College of Chemical and Biological \\ Engineering, Shandong University of Science and Technology, Qingdao, 277590, China. \\ ${ }^{2}$ State Key Laboratory of Heavy Oil Processing, China University of Petroleum (East China), Qingdao 266580, \\ China.
}

*Corresponding author: Haifeng Zhou, email: zhou_hf@sdust.edu.cn, Phone: +86-532-86057766.

Received August 12 $2^{\text {th }}, 2020$; Accepted February $4^{\text {th }}, 2021$.

DOI: http://dx.doi.org/10.29356/jmcs.v65i3.1427

\begin{abstract}
Utilization of the huge quantity of sawdust wastes is urgent. In this study, SPORL, dilute acid pretreatment (DA), formic acid pretreatment $(\mathrm{FA})$, ethanol pretreatment $\left(\mathrm{EtOH} / \mathrm{H}_{2} \mathrm{O}\right)$, and sulfuric acid catalyzed ethanol pretreatment $\left(\mathrm{EtOH} / \mathrm{H}_{2} \mathrm{O} / \mathrm{H}_{2} \mathrm{SO}_{4}\right)$, on improving enzymatic hydrolysis of mixed sawdust wastes were comprehensively compared. EtOH/ $\mathrm{H}_{2} \mathrm{O} / \mathrm{H}_{2} \mathrm{SO}_{4}$ was the most effective pretreatment in lignin removal from sawdust fiber cell wall, while FA was much more effective in hemicellulose removal. After the pretreatments, the crystallinity of cellulose increased because of the removal of amorphous hemicellulose and lignin. Moreover, the fiber surface became coarse and porous, especially after $\mathrm{EtOH} / \mathrm{H}_{2} \mathrm{O} / \mathrm{H}_{2} \mathrm{SO}_{4}$, the structure was destroyed into fragments, which enhanced the cellulase accessibility of cellulose. Therefore, the glucose yield of EtOH/ $\mathrm{H}_{2} \mathrm{O} / \mathrm{H}_{2} \mathrm{SO}_{4}$ pretreated substrate was highest among these five pretreatments, achieved at $91.4 \%$ with a cellulase loading of only $10 \mathrm{FPU} / \mathrm{g}$ glucan.
\end{abstract}

Keywords: Mixed sawdust wastes; pretreatments; enzymatic hydrolysis; delignification.

Resumen. Es urgente aprovechar la gran cantidad de residuos de aserrín. En este estudio, SPORL, pretratamiento con ácido diluido (DA), pretratamiento con ácido fórmico (FA), pretratamiento con etanol $\left(\mathrm{EtOH} / \mathrm{H}_{2} \mathrm{O}\right)$ y pretratamiento con etanol catalizado con ácido sulfúrico $\left(\mathrm{EtOH} / \mathrm{H}_{2} \mathrm{O} / \mathrm{H}_{2} \mathrm{SO}_{4}\right)$, sobre la mejora de la hidrólisis enzimática de residuos de aserrín mezclado fueron comparados de manera integral. $\mathrm{EtOH} / \mathrm{H}_{2} \mathrm{O} / \mathrm{H}_{2} \mathrm{SO}_{4}$ fue el pretratamiento más eficaz para eliminar la lignina de la pared celular de la fibra de aserrín, mientras que el FA fue mucho más eficaz para eliminar la hemicelulosa. Después de los pretratamientos, la cristalinidad de la celulosa aumentó debido a la eliminación de hemicelulosa amorfa y lignina. Además, la superficie de la fibra se volvió gruesa y porosa, especialmente después de EtOH/ $\mathrm{H}_{2} \mathrm{O} / \mathrm{H}_{2} \mathrm{SO}_{4}$, la estructura se destruyó en fragmentos, lo que mejoró la accesibilidad de celulasa de la celulosa. Por lo tanto, el rendimiento de glucosa del sustrato pretratado con $\mathrm{EtOH} / \mathrm{H}_{2} \mathrm{O} / \mathrm{H}_{2} \mathrm{SO}_{4}$ fue el más alto entre estos cinco pretratamientos, alcanzado al $91,4 \%$ con una carga de celulasa de solo $10 \mathrm{FPU} / \mathrm{g}$ de glucano.

Palabras clave: Residuos de aserrín mezclados; pretratamientos; hidrólisis encimática; deslignificación. 


\section{Introduction}

Lignocellulosic materials are recognized as a low-cost and sustainable feedstock for solving the energy and environmental issues arising from fossil fuel [1,2]. The global annual production of lignocellulosic residues from forest processing industry, such as sawdust, bark, and other wood wastes, is approximately 180 million of cubic metric $[3,4]$. Among these wood wastes, sawdust is found approximately $42 \%$. Moreover, more than $67 \%$ of sawdust is located in Brazil, Canada, and China [4]. The huge quantities of sawdust wastes are generated mainly from sawmills, laminated lumber factories, furniture manufactures, and so on [5]. Therefore, how to utilize these sawdust wastes is urgent. Recently, some studies indicated that sawdust could be used as a promising feedstock for biofuel production [6]. During the biofuel production, enzymatic hydrolysis of wood structural carbohydrates is a critical step. However, the biomass recalcitrance is a key limit for cheaply releasing sugars from sawdust. Due to the tight linkage of lignin, hemicellulose and cellulose, the cellulase accessibility to cellulose is limited. Therefore, the pretreatment of sawdust is necessary. The purpose of pretreatments includes removing lignin and hemicellulose, decreasing the cellulose crystallinity and increasing the porosity of the substrate, thereby, enhancing enzymatic digestibility of cellulose [7]. To date, various pretreatment technologies have been investigated, which can be broadly classified into four categories, such as physical, chemical, biological pretreatments and their combinations [8-10]. Among all of the currently available and widely used pretreatment methods, chemical pretreatments are most commonly used due to the economic reason [11].

Dilute acid pretreatment (DA), the most widely studied process, was commercially applied from the beginning of $20^{\text {th }}$ century. The usually used acid concentration for DA is below $5 \%$. It works at $120-190^{\circ} \mathrm{C}$ for several minutes to $90 \mathrm{~min}$ [10]. The application of DA for hardwood sawdust showed $41 \%$ and $62 \%$ of glucose yield for aspen and birch chips, respectively [12]. When catalpa sawdust was treated by $5 \%(\mathrm{w} / \mathrm{v})$ of $\mathrm{H}_{2} \mathrm{SO}_{4}$ or $\mathrm{HCl}$ at $100^{\circ} \mathrm{C}$ for $1 \mathrm{~h}$, the reducing sugar yield slightly decreased comparing with that from the raw catalpa sawdust, only about $25 \mathrm{mg} / \mathrm{g}$ [13]. In another work, addition of $4 \mathrm{wt} \%$ (based on oven dried sawdust) 2naphthol-7-sulfonate in the combined DA pretreatment enhanced the enzymatic hydrolysis of DA by $47.8 \%$ [14].

The development of sulfite pretreatment to overcome recalcitrance of lignocellulose (SPORL) process is based on the fundamental understandings of sulfite pulping, which is a combined pretreatment of using sulfuric acid and sodium bisulfite to pretreat lignocellulose at high temperature followed by size reduction with a disk milling [15]. It has been demonstrated for robust and efficient bioconversion of woody biomass [15-17]. After SPORL pretreatment at $165^{\circ} \mathrm{C}$ for 75 min with sulfuric acid and sodium bisulfite loading of 2.2 and $8 \%$ on beetle-killed lodgepole pine, glucose yields were approximately $90 \%$ [16]. When spruce chips were treated by SPORL process with $8-10 \%$ sodium bisulfite and $1.8-3.7 \%$ sulfuric acid (based on oven dried wood) at $180^{\circ} \mathrm{C}$ for $30 \mathrm{~min}$, more than $90 \%$ cellulose conversion could be obtained [15].

Organosolv pretreatment not only well enhances the cellulose digestibility but also produces three separate fractions including high purity lignin, an aqueous hemicellulose enriched stream, and cellulose fibers $[6,18]$. Due to the low toxicity, high volatility and easiness of recycling of ethanol, ethanosolv pretreatment has been used for various feedstocks [19-21]. Quercus $s p$. sawdust was pretreated by sulfuric acid catalyzed ethanol pretreatment $\left(\mathrm{EtOH} / \mathrm{H}_{2} \mathrm{O} / \mathrm{H}_{2} \mathrm{SO}_{4}\right)$ at $146^{\circ} \mathrm{C}$ for $15 \mathrm{~min}$ with $0.05 \mathrm{~mol} / \mathrm{dm}^{3} \mathrm{H}_{2} \mathrm{SO}_{4}$ as a catalyst, the delignification achieved at $89.77 \%$, and the cellulose recovery was $85.42 \%$ [6]. Formic acid represents a good solubility of lignin. Zhao and Liu [22] proposed a Formiline process with formic acid delignification followed by alkaline deformylation, after which, more than $80 \%$ of lignin and hemicellulose in sugarcane bagasse were removed. Therefore, the glucan conversion increased to $84.4 \%$ with cellulase loading of $20 \mathrm{FPU} / \mathrm{g}$ solid.

Although researchers have been made a lot of effort on building efficient and environmental benign pretreatment methods [23], little research has been found on systematically comparing SPORL, DA, FA, $\mathrm{EtOH} / \mathrm{H}_{2} \mathrm{O}, \mathrm{EtOH} / \mathrm{H}_{2} \mathrm{O} / \mathrm{H}_{2} \mathrm{SO}_{4}$ of the mixed sawdust wastes. For different feedstock species, the influences of different types of pretreatment technologies on enhancing the enzymatic digestibility are diverse. Therefore, further comparison of these pretreatments for scale up design and economic evaluation are impossible. The aim of this study is thus to systematically compare these pretreatments of mixed sawdust wastes in terms of composition analysis, enzymatic hydrolysis, and substrate structure characterization. 


\section{Experimental}

\section{Materials and Methods Materials}

Mixed sawdust wastes were provided by Jiaonan Longquan Wood Processing Co. Ltd. (Qingdao, China). Sawdust was used as received without any further treatments.

Commercial cellulase enzyme Cellic CTec2 was purchased from Novozymes China (Shanghai, China). The filter paper activity of CTec2 was $110 \mathrm{FPU} / \mathrm{mL}$ as calibrated according to Wood and Bhat [24]. All chemicals, such as sulfuric acid, ethanol, sodium bisulfite, were analytical grade.

\section{Pretreatments}

All pretreatments were carried out in the pressure reactor (BFK-2L, Borui Chemical Machinery, Shandong, China). According to our previous SPORL pretreatment research [16-17,25], the liquid to sawdust ratio of SPORL pretreatment was fixed at $6(\mathrm{v} / \mathrm{w})$. Sawdust of $200 \mathrm{~g}$ was pretreated at $170^{\circ} \mathrm{C}$ for $25 \mathrm{~min}$. The sodium bisulfite and sulfuric acid loading on oven dried sawdust was 16 and $4.4 \mathrm{wt} \%$, respectively. After the pretreatment, the liquid and solid phases were separated by filtration under vacuum. The solid phase was washed with distilled water.

For the dilute acid pretreatment (DA), the solid-liquid ratio, sulfuric acid loading, reaction temperature and time, and processing of the treated solids were the same as SPORL pretreatment except for sodium bisulfite.

Formic acid pretreatment (FA) of sawdust $(200 \mathrm{~g})$ was carried out at $101^{\circ} \mathrm{C}$ for $60 \mathrm{~min}$ with a liquidsolid ratio of $6: 1(\mathrm{w} / \mathrm{v})$ using $78 \%$ formic acid solution. After pretreatment, the liquid and solid phases were separated by filtration under vacuum. The solid phase was washed with $78 \%$ formic acid solution. Subsequently, the washed solids were treated at $120{ }^{\circ} \mathrm{C}$ for 60 min using $600 \mathrm{~mL}$ of $2 \mathrm{w} / \mathrm{w} \% \mathrm{Ca}(\mathrm{OH})_{2}$ (based on the weight of initial sawdust). Finally, the solids were collected and washed with distilled water.

Ethanol pretreatment $\left(\mathrm{EtOH} / \mathrm{H}_{2} \mathrm{O}\right)$ of sawdust was conducted at $170{ }^{\circ} \mathrm{C}$ for $60 \mathrm{~min}$ with a liquid-solid ratio of 7:1 (v/w) using $65 \%$ aqueous ethanol solution. After pretreatment, the liquid and solid phases were separated by filtration under vacuum. The solid phase was washed three times with $300 \mathrm{~mL}$ aqueous ethanol solution at $60^{\circ} \mathrm{C}$, and then washed with distilled water.

Sulfuric acid catalyzed ethanol pretreatment $\left(\mathrm{EtOH} / \mathrm{H}_{2} \mathrm{O} / \mathrm{H}_{2} \mathrm{SO}_{4}\right)$ of sawdust was the same as $\mathrm{EtOH} / \mathrm{H}_{2} \mathrm{O}$ except for adding $1.1 \mathrm{wt} \% \mathrm{H}_{2} \mathrm{SO}_{4}$ on sawdust.

All the washed solids were stored in a refrigerator at $4{ }^{\circ} \mathrm{C}$ until use. To ensure the repeatability of the experiments, at least two duplicate runs were performed.

\section{Enzymatic hydrolysis}

Enzymatic hydrolysis of pretreated sawdust was carried out in duplicates at $2 \%(\mathrm{w} / \mathrm{v})$ as described previously [26-27]. Briefly, $1 \mathrm{~g}$ of pretreated sawdust and $50 \mathrm{~mL}$ of acetate buffer $(\mathrm{pH}=5.5)$ were placed in a $150 \mathrm{~mL}$ conical flask in a shaking incubator at $50^{\circ} \mathrm{C}$ and $200 \mathrm{rpm}$. The CTec2 loading was 10 and $20 \mathrm{FPU} / \mathrm{g}$ glucan. Aliquots of $1 \mathrm{~mL}$ were taken periodically for glucose determination after centrifuged at $10,000 \mathrm{rpm}$ for $5 \mathrm{~min}$. Glucose in the hydrolysate was measured in duplicate using a commercial glucose analyzer (SBA-40E biosensor, Institute of Biology of the Shandong Academy of Sciences, China). Glucose yield, defined as the glucose content in hydrolysate as a percentage of the theoretical glucose available in the substrates, was used to represent the enzymatic hydrolysis efficiency. The average of two replicate hydrolysis runs and their errors were reported to ensure the reproducibility of the results.

\section{Characterization of substrates}

The chemical compositions of untreated and pretreated sawdust were determined by a two-step acid hydrolysis procedure, as described previously [16]. Two duplicate runs were carried out and the average of them was reported.

Fourier transform infrared spectroscopy (FTIR) was performed using a Nicolet 380 FT-IR spectrometer (Thermo Nicolet Co., USA). The spectra were recorded between 4,000 and $500 \mathrm{~cm}^{-1}$. Disks were prepared by mixing finely ground samples and spectroscopic grade $\mathrm{KBr}$ with a weight ratio of 1:100. 
The crystallinity of the pretreated samples was analyzed by X-ray diffractometry (XRD). XRD spectra were recorded by Rigaku Utima IV (Rigaku Corporation, Japan), which was operated at a voltage of $40 \mathrm{kV}$ and a current of $40 \mathrm{~mA}$. The $2 \theta$ range was from $5^{\circ}$ to $90^{\circ}$ in steps of $0.02^{\circ}$. Crystallinity index (CrI) of samples was calculated by: $\mathrm{CrI}=\left[\left(I_{002}-I_{\mathrm{am}}\right) / I_{002}\right] \times 100 \%$, where $I_{002}$ indicates the maximum intensity of the diffraction angle of the lattice, and $I_{\mathrm{am}}$ represents the scattering intensity of the amorphous background diffraction.

The morphologies of the pretreated samples were characterized by a Scanning electron microscope (SEM) (Apreo, FEI, Hillsboro, USA).

\section{Results and discussion}

\section{Composition analysis of the pretreated sawdust}

Because of the crucial barriers of lignin and hemicellulose of woody biomass, the most important aim of pretreatment is to solubilize lignin and hemicellulose as much as possible [28]. As shown in Table 1, $\mathrm{EtOH} / \mathrm{H}_{2} \mathrm{O} / \mathrm{H}_{2} \mathrm{SO}_{4}$ obtained the lowest solid recovery, which was due to the considerable depolymerization and solubilization of lignin and hemicellulose components. Particularly, EtOH/ $\mathrm{H}_{2} \mathrm{O} / \mathrm{H}_{2} \mathrm{SO}_{4}$ had the largest delignification degree and removed more than $85 \%$ of hemicellulose. Therefore, the pretreated sawdust contained the highest cellulose content, around $72 \%$. In a previous study [29], after EtOH/ $\mathrm{H}_{2} \mathrm{O} / \mathrm{H}_{2} \mathrm{SO}_{4}$ pretreatment, the lodgepole pine was almost free from hemicellulose and contained approximately $80 \%$ of cellulose. EtOH/ $\mathrm{H}_{2} \mathrm{O}$ also removed considerable part of lignin, but the hemicellulose removal was much lower than that of EtOH$/ \mathrm{H}_{2} \mathrm{O} / \mathrm{H}_{2} \mathrm{SO}_{4}$. This was because that sulfuric acid addition in $\mathrm{EtOH} / \mathrm{H}_{2} \mathrm{O} / \mathrm{H}_{2} \mathrm{SO}_{4}$ was beneficial to solubilize lignin and hemicellulose. FA removed the most hemicellulose fraction; thereby, the residual hemicellulose content of the pretreated sawdust was as low as $2.1 \%$. Nevertheless, FA had a poorer solubilizing ability to lignin than $\mathrm{EtOH} / \mathrm{H}_{2} \mathrm{O} / \mathrm{H}_{2} \mathrm{SO}_{4}, \mathrm{EtOH} / \mathrm{H}_{2} \mathrm{O}$ and SPORL. The lignin removal of FA was different from the previous researches for wheat straw [18], oil palm empty fruit bunches [30], and sugarcane bagasse [31], while the hemicellulose removal was comparable. This difference was mainly due to the high lignin content and its great degree of cross-linking in woody biomass [32-33]. SPORL has been demonstrated of good performance for woody biomass, which is effective on solubilization of lignin and hemicellulose [16]. After SPORL, the lignin and hemicellulose removal was 53.1 and $65.9 \%$, respectively (Table 1 ). Thus, the cellulose retained in the SPORL pretreated sawdust was $55.4 \%$, higher than the one in untreated sawdust. In addition, because of the high solid recovery, the cellulose recovery of SPORL was highest. Although SPORL removed parts of lignin and hemicellulose, the efficiency of SPORL was not very prominent for this mixed sawdust wastes among these five pretreatment methods. DA has been known to be effective in selective hydrolysis of the hemicellulose component [34]. As observed in Table 1, the hemicellulose retained in DA pretreated sawdust was $10 \%$; however, the lignin content was as high as $45.6 \%$. DA had the worst solubilizing ability to lignin among these five pretreatment methods, and obtained the highest solid recovery. Nevertheless, due to partial solubilization of cellulose, the cellulose recovery of DA was medium. The order of hemicellulose content in pretreated sawdust was $\mathrm{FA}<\mathrm{DA}<\mathrm{EtOH} / \mathrm{H}_{2} \mathrm{O} / \mathrm{H}_{2} \mathrm{SO}_{4}<\mathrm{SPORL}<\mathrm{EtOH} / \mathrm{H}_{2} \mathrm{O}$, whereas, the order of lignin content was $\mathrm{EtOH} / \mathrm{H}_{2} \mathrm{O} / \mathrm{H}_{2} \mathrm{SO}_{4}<\mathrm{EtOH} / \mathrm{H}_{2} \mathrm{O}<\mathrm{SPORL}<\mathrm{FA}<$ DA.

\section{Enzymatic hydrolysis of pretreated sawdust}

The effectiveness of various pretreatments carried out on sawdust was investigated by enzymatic hydrolysis using two cellulase dosages. The glucose yield of pretreated sawdust after enzymatic hydrolysis was shown in Fig. 1. Compared with the other pretreatments, EtOH/ $\mathrm{H}_{2} \mathrm{O} / \mathrm{H}_{2} \mathrm{SO}_{4}$ was the most efficient method to improve the enzymatic hydrolysis of sawdust. The maximum glucose yield of $\mathrm{EtOH} / \mathrm{H}_{2} \mathrm{O} / \mathrm{H}_{2} \mathrm{SO}_{4}$ pretreated sawdust reached $91.4 \%$ at only $10 \mathrm{FPU} / \mathrm{g}$ of cellulase, which was far superior to the other pretreatments in the present manuscript. The glucose yield was in accordance with the ones obtained with $\mathrm{EtOH} / \mathrm{H}_{2} \mathrm{O} / \mathrm{H}_{2} \mathrm{SO}_{4}$ pretreated beetle killed and healthy lodgepole pine (around $90 \%$ at $20 \mathrm{FPU} / \mathrm{g}$ cellulase). However, if severer pretreatment conditions were applied, the glucose yield could achieve at $100 \%$ [29]. Different from $\mathrm{EtOH} / \mathrm{H}_{2} \mathrm{O} / \mathrm{H}_{2} \mathrm{SO}_{4}, \mathrm{EtOH} / \mathrm{H}_{2} \mathrm{O}$ showed poor enzymatic hydrolysis efficiency, the glucose yield of which was only $11.2 \%$. The similar result was reported for $\mathrm{EtOH} / \mathrm{H}_{2} \mathrm{O}$ pretreated wheat straw with or without $0.02 \mathrm{M} \mathrm{HCl}$ [35], the maximal glucose yield of which was $99 \%$ and $44 \%$, respectively. SPORL and DA also represented 
poor enzymatic hydrolysis efficiency, the glucose yield of which was 14.3 and $10.3 \%$, respectively. The glucose yield of SPORL pretreated sawdust was far below the level (around 70\%) reported previously [16,17]. This difference was mainly due to the high hemicellulose content (18.8\%) in SPORL pretreated sawdust, while it was approximately $10 \%$ in previous SPORL pretreated woody biomass. In terms of DA, the low glucose yield was mainly due to the pretty high lignin content in the substrate. FA showed better glucose yield of $23.9 \%$, but still far below that from EtOH/ $\mathrm{H}_{2} \mathrm{O} / \mathrm{H}_{2} \mathrm{SO}_{4}$ and the previous researches for wheat straw [18], oil palm empty fruit bunches [30], and sugarcane bagasse [31]. The low cellulose conversion of FA pretreated sawdust was mainly due to the low lignin removal.

Generally, increasing the cellulase dosage from $10 \mathrm{FPU} / \mathrm{g}$ to $20 \mathrm{FPU} / \mathrm{g}$ glucan, the glucose yield was enhanced. Especially for DA pretreatment, the glucose yield increased by 120\% (Fig. 1(b)). In terms of FA, SPORL, and EtOH $/ \mathrm{H}_{2} \mathrm{O}$ pretreated sawdust, the increase was relatively lower than that of DA pretreated sample, only $54 \%, 37 \%$, and $56 \%$, respectively. With cellulase dosage of $20 \mathrm{FPU} / \mathrm{g}$ glucan, the glucose yield of DA, SPORL, and $\mathrm{EtOH} / \mathrm{H}_{2} \mathrm{O}$ pretreated sawdust was $22.7 \%, 19.6 \%$, and $17.5 \%$, respectively. These results were only comparable to the untreated sugarcane bagasse [36], which indicated that the sawdust was especially recalcitrant to enzymatic hydrolysis. For EtOH/ $\mathrm{H}_{2} \mathrm{O} / \mathrm{H}_{2} \mathrm{SO}_{4}$ pretreated sample, the terminal glucose yield was almost no change with increasing cellulase dosage; however, the enzymatic hydrolysis rate was faster.

In order to further investigate the effectiveness of $\mathrm{EtOH} / \mathrm{H}_{2} \mathrm{O} / \mathrm{H}_{2} \mathrm{SO}_{4}, 5 \mathrm{FPU} / \mathrm{g}$ cellulase was applied to the enzymatic hydrolysis, as shown in Fig. 1(c). The glucose yield achieved at $63.9 \%$, better than other pretreatments with $20 \mathrm{FPU} / \mathrm{g}$ cellulase. It indicated that $\mathrm{EtOH} / \mathrm{H}_{2} \mathrm{O} / \mathrm{H}_{2} \mathrm{SO}_{4}$ was very appropriate for this mixed sawdust wastes. When $15 \mathrm{mg} / \mathrm{g}$ PEG was added to the substrate, the enzymatic hydrolysis increased by $39 \%$, achieved at $88.6 \%$.
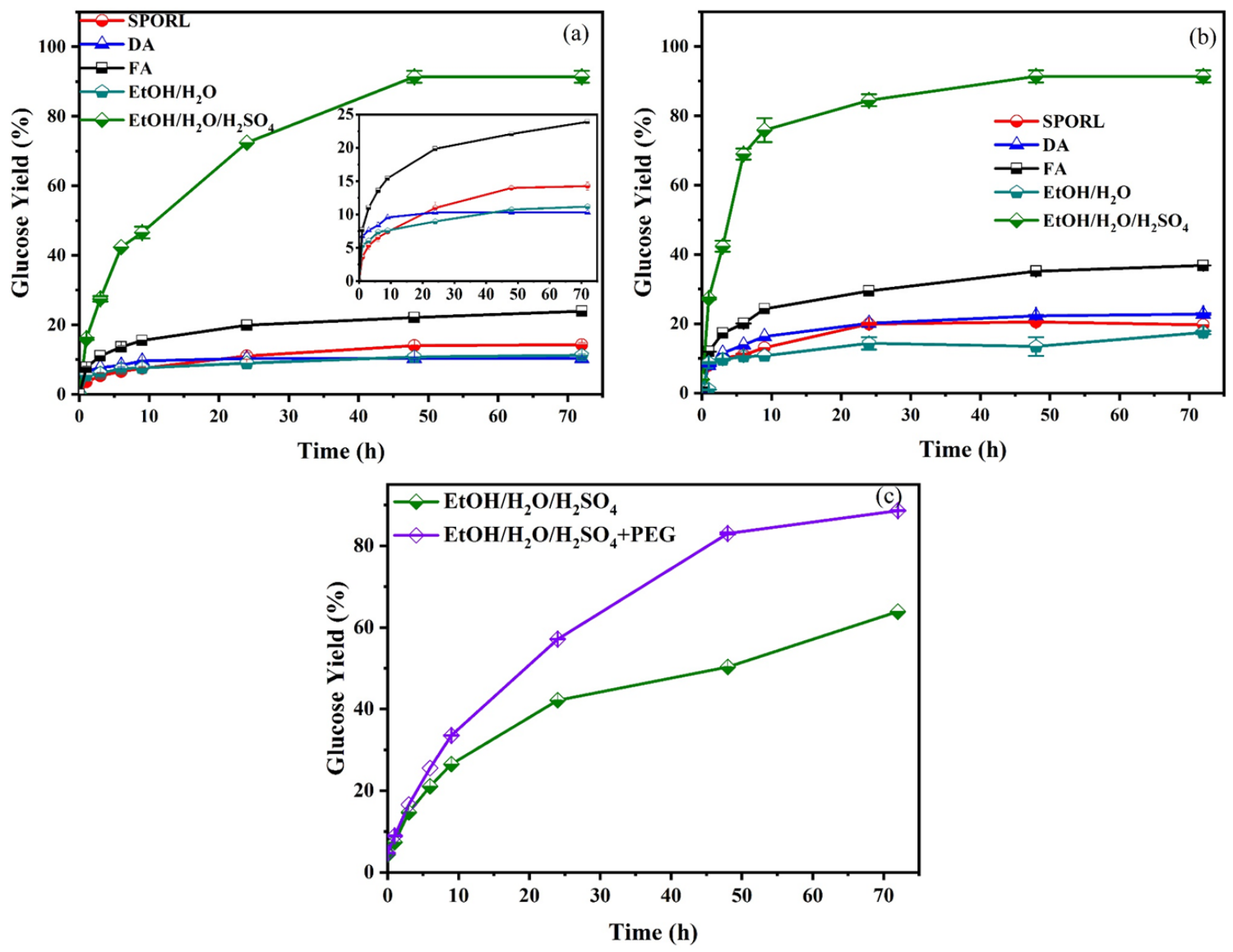

Fig. 1. The enzymatic hydrolysis of sawdust after different pretreatments with cellulase loadings of (a) 10 FPU/g glucan, (b) $20 \mathrm{FPU} / g$ glucan, and (c) $5 \mathrm{FPU} / \mathrm{g}$ glucan. 


\section{Surface morphology of sawdust after pretreatments}

Scanning electron microscope (SEM) was executed to investigate the surface morphology of untreated and pretreated sawdust. As observed in Fig. 2(a), raw sawdust had a non-porous, compact and smooth surface, which was an obstacle for cellulase accessibility. After the pretreatments, the surface became coarse and porous (Fig. 2(b-f)). In addition, the cellulose fibers became separated because of the removal of lignin and hemicellulose. Especially for EtOH/ $\mathrm{H}_{2} \mathrm{O} / \mathrm{H}_{2} \mathrm{SO}_{4}$ pretreated sawdust, cracks, penetrations, and some particles depositions could be obviously observed (Fig. 2(f)), indicating that the compact structure was disrupted. The particles depositions might be due to the re-precipitation of dissolved lignin and the formation of "pseudolignin", as the other researchers reported [6,18,37,38]. Moreover, different from the other pretreatments, the structure after $\mathrm{EtOH} / \mathrm{H}_{2} \mathrm{O} / \mathrm{H}_{2} \mathrm{SO}_{4}$ was destroyed into fragments, which was beneficial to enzymatic hydrolysis. Without $\mathrm{H}_{2} \mathrm{SO}_{4}$ as catalysis, only cracks, pores and rough surface occurred during EtOH/ $\mathrm{H}_{2} \mathrm{O}$ (Fig. 2(e)). Compared with $\mathrm{EtOH} / \mathrm{H}_{2} \mathrm{O}, \mathrm{EtOH} / \mathrm{H}_{2} \mathrm{O} / \mathrm{H}_{2} \mathrm{SO}_{4}$ pretreated sawdust showed much better cellulase accessibility, thereby, obtaining much higher glucose yield. Due to the considerable removal of hemicellulose, FA pretreated sawdust represented deeper cracks, rougher surfaces than SPORL and DA, which implied the enhancement of cellulase accessibility. After DA, many slight breaks generated on the fiber surface as a consequence of hemicellulose removal. In general, the surface morphologies changes of SPORL and EtOH/ $\mathrm{H}_{2} \mathrm{O}$ pretreated sawdust were relatively small. This might be attributed to the lower hemicellulose removal, since hemicellulose acted as adhesives to connect cellulose and lignin in the cell walls $[39,40]$.

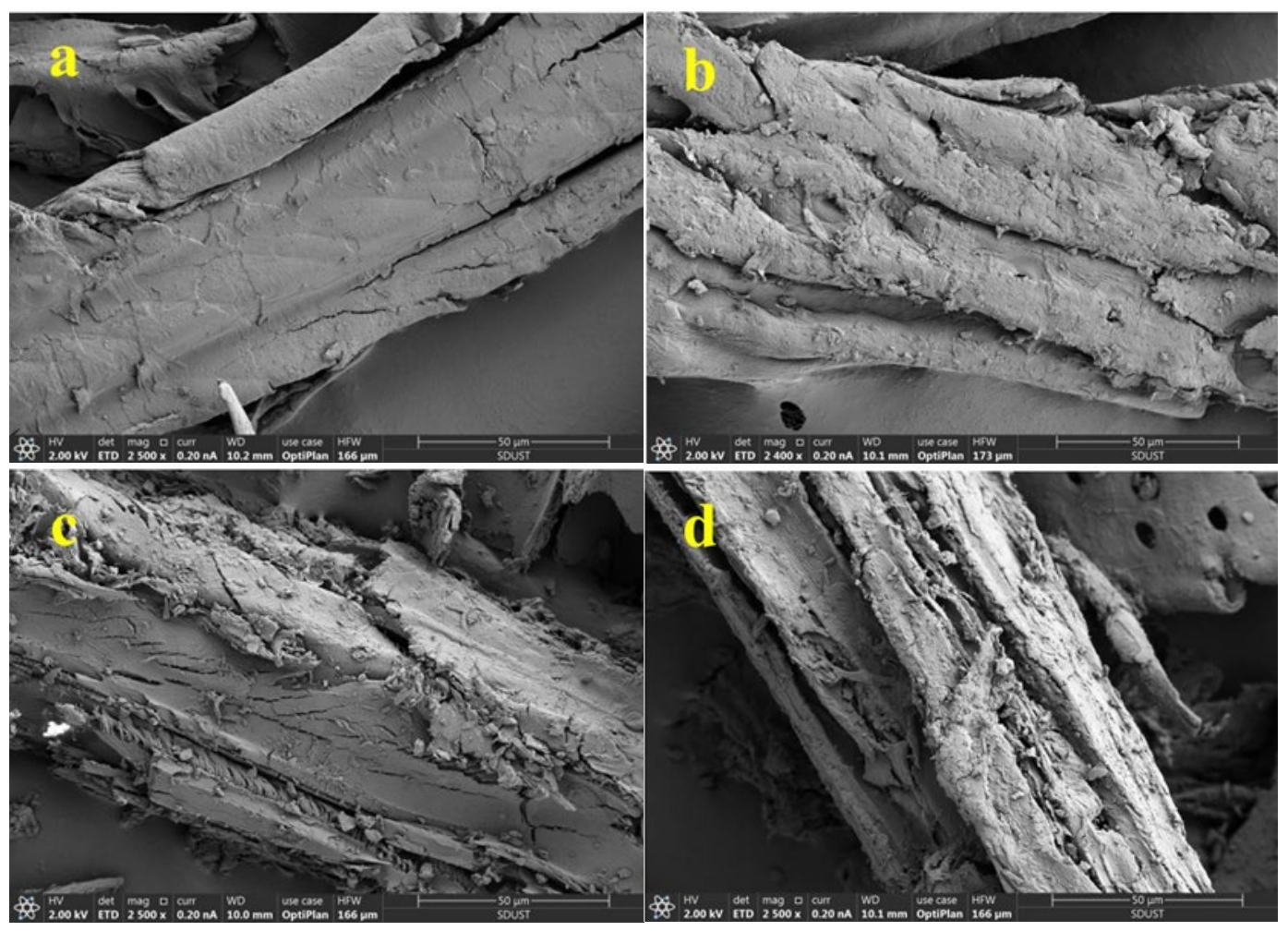




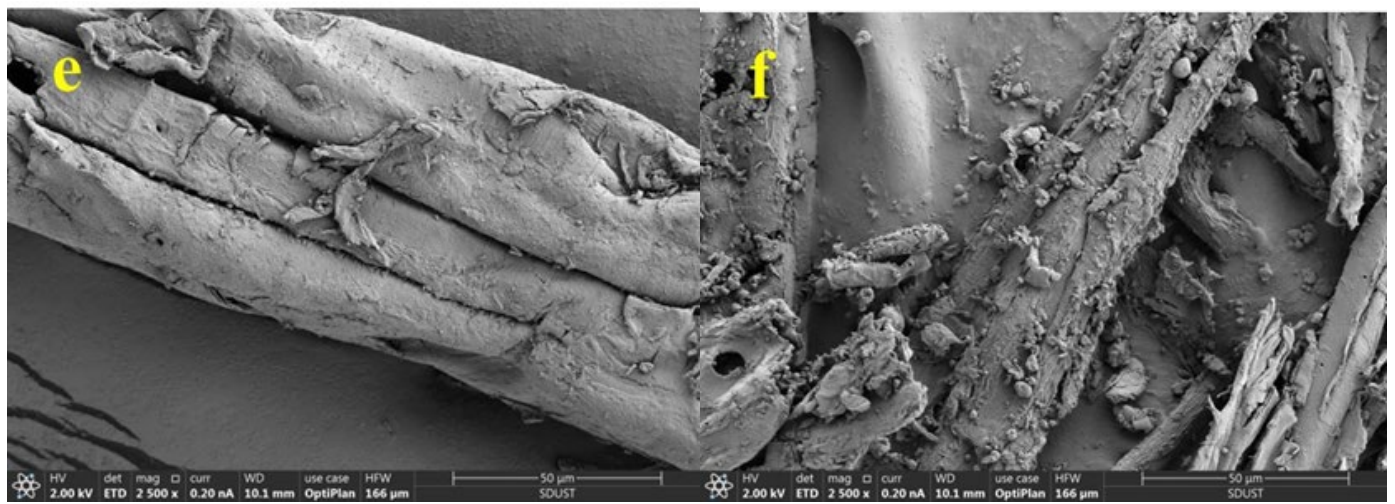

Fig. 2. SEM images of the untreated and pretreated sawdust ((a) Raw sawdust; (b) SPORL; (c) DA; (d) FA; (e) $\mathrm{EtOH} / \mathrm{H}_{2} \mathrm{O} ;\left(\right.$ f) $\mathrm{EtOH} / \mathrm{H}_{2} \mathrm{O} / \mathrm{H}_{2} \mathrm{SO}_{4}$ ).

\section{FTIR analysis of pretreated sawdust}

FTIR analysis was used to investigate the chemical structure changes of untreated and pretreated sawdust. As shown in Fig. 3, three main components were present in the analyzed substrates. The broad adsorption band around $3400 \mathrm{~cm}^{-1}$ was attributed to the stretch of $-\mathrm{OH}$ group and the peak at $2910 \mathrm{~cm}^{-1}$ was assigned to $-\mathrm{CH}$ stretching [41]. The peak around $1733 \mathrm{~cm}^{-1}$, observed for untreated raw sawdust, was assigned to the stretching vibration of $\mathrm{C}=\mathrm{O}$ in acetyl and uronic ester groups connected to branched chains of hemicellulose [42]. This band was weakened for SPORL and EtOH/ $\mathrm{H}_{2} \mathrm{O}$ pretreated sawdust, absent for DA, FA, and $\mathrm{EtOH} / \mathrm{H}_{2} \mathrm{O} / \mathrm{H}_{2} \mathrm{SO}_{4}$ pretreated sawdust. It indicated a significant removal of acetyl group and hemicellulose after pretreatments. Peaks at 1620,1512 , and $1400 \mathrm{~cm}^{-1}$ were attributed to the aromatic skeleton vibration of lignin [41]. Compared with untreated sawdust, DA and FA pretreated sawdust showed stronger intensities at these bands, while the band intensities of SPORL, EtOH/ $\mathrm{H}_{2} \mathrm{O}$, and $\mathrm{EtOH} / \mathrm{H}_{2} \mathrm{O} / \mathrm{H}_{2} \mathrm{SO}_{4}$ pretreated sawdust were weaker than that of untreated sawdust. The band at $897 \mathrm{~cm}^{-1}$, corresponding to the $\beta-(1-4)-$ glycosidic bond (C-O-C), was the characteristic peak of cellulose [43]. After pretreatments, the intensity of this peak was stronger than that of untreated sawdust, indicating that most of the cellulose remained after pretreatments and the cellulose content was higher. These results were in accordance with those of composition analysis (Table 1).

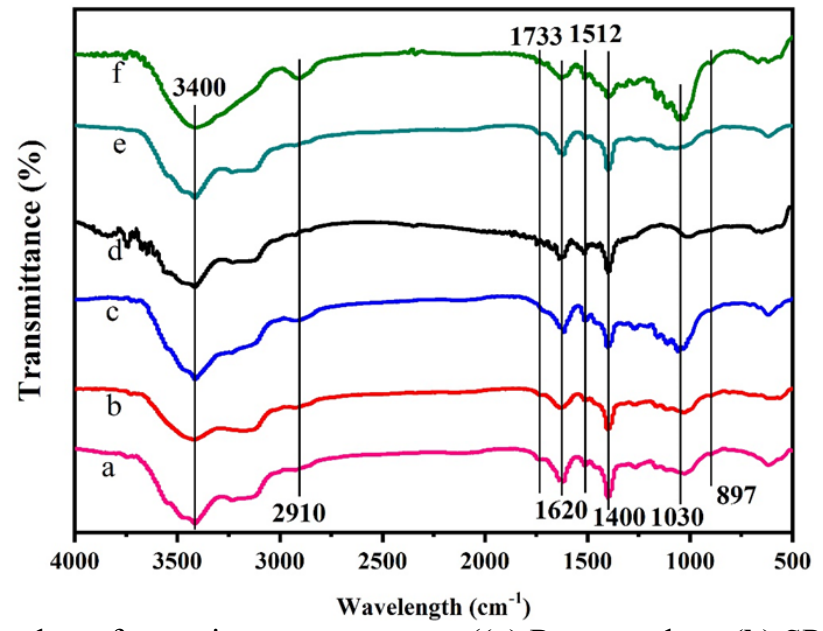

Fig. 3. FTIR spectra of sawdust after variety pretreatments ((a) Raw sawdust; (b) SPORL; (c) DA; (d) FA; (e) $\mathrm{EtOH} / \mathrm{H}_{2} \mathrm{O}$; (f) $\mathrm{EtOH} / \mathrm{H}_{2} \mathrm{O} / \mathrm{H}_{2} \mathrm{SO}_{4}$ ). 


\section{X-ray diffraction (XRD) analysis of pretreated sawdust}

In order to further compare the crystallinities of the pretreated sawdust, XRD diffractograms of pretreated and untreated sawdust were recorded. As shown in Fig. 4, for all the substrates, there were three main reflections, namely $I_{1-10}, I_{110}$, and $I_{200}$, located at $14.8^{\circ}, 16.5^{\circ}$, and $22.2^{\circ}$, respectively [6,23]. The amorphous background diffraction was around $18.3^{\circ}$. The calculated crystallinity index (CrI) for untreated sawdust, SPORL, DA, FA, EtOH $/ \mathrm{H}_{2} \mathrm{O}$, and $\mathrm{EtOH} / \mathrm{H}_{2} \mathrm{O} / \mathrm{H}_{2} \mathrm{SO}_{4}$ pretreated sawdust was $22.4 \%, 37.8 \%, 27.5 \%, 30.0 \%$, $38.8 \%$, and $55.6 \%$, respectively. Generally, pretreated substrates represented higher CrI than untreated sawdust, which was mainly attributed to the removal of amorphous hemicellulose and lignin during pretreatments. The highest crystallinity was observed for EtOH/ $\mathrm{H}_{2} \mathrm{O} / \mathrm{H}_{2} \mathrm{SO}_{4}$ pretreated sawdust, while DA pretreated sawdust showed the lowest CrI among the five pretreated substrates. The CrI seemed to be positively correlated with the lignin removal. The more the delignification was, the higher the CrI was, as shown in Table 1. The similar relationship between the delignification and CrI was reported for Ethanosolv pretreated Quercus $s p$. Sawdust [6]. On the other hand, the selective hydrolysis of amorphous cellulose during pretreatments was also a reason for $\mathrm{CrI}$ increase [29].

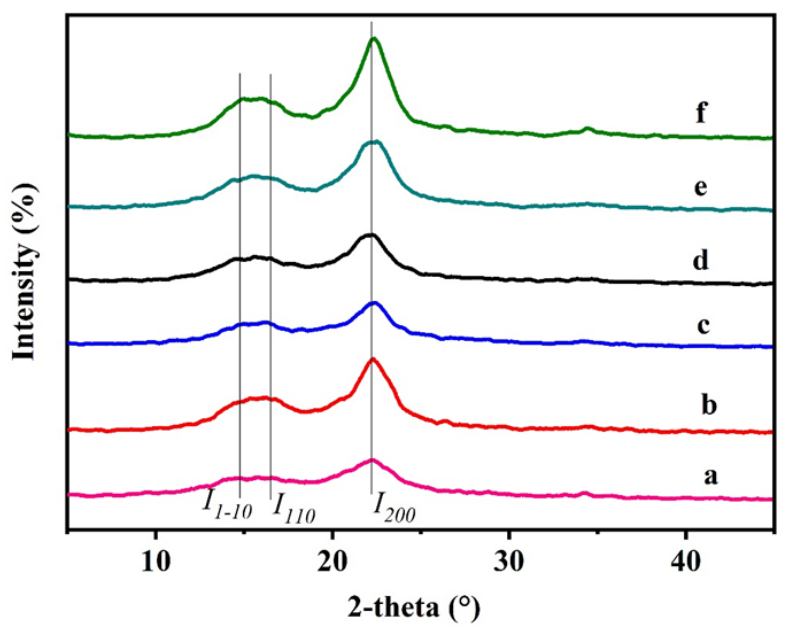

Fig. 4. XRD diffractograms of sawdust after variety pretreatments ((a) Raw sawdust; (b) SPORL; (c) DA; (d) $\mathrm{FA}$; (e) $\mathrm{EtOH} / \mathrm{H}_{2} \mathrm{O}$; (f) $\mathrm{EtOH} / \mathrm{H}_{2} \mathrm{O} / \mathrm{H}_{2} \mathrm{SO}_{4}$ ).

\section{Conclusion}

Five pretreatment technologies of sawdust under respective optimal conditions were compared in terms of enzymatic hydrolysis, composition analysis and structural features of the pretreated substrates. Ethanosolv pretreatments showed higher degree of delignification but lower solid recovery than the other pretreatments. Different from EtOH/ $\mathrm{H}_{2} \mathrm{O}, \mathrm{EtOH} / \mathrm{H}_{2} \mathrm{O} / \mathrm{H}_{2} \mathrm{SO}_{4}$ represented good hemicellulose removal as well. Therefore, $\mathrm{EtOH} / \mathrm{H}_{2} \mathrm{O} / \mathrm{H}_{2} \mathrm{SO}_{4}$ obtained the highest final glucose yield, which was the most appropriate pretreatment for this waste mixed sawdust. Structural features analysis demonstrated that after EtOH/ $\mathrm{H}_{2} \mathrm{O} / \mathrm{H}_{2} \mathrm{SO}_{4}$ pretreatment, the recalcitrant and compact structure of sawdust was particularly disrupted. The cellulase accessibility of cellulose in EtOH/ $\mathrm{H}_{2} \mathrm{O} / \mathrm{H}_{2} \mathrm{SO}_{4}$ pretreated substrates was consequently enhanced. However, the other pretreatments, including $\mathrm{EtOH} / \mathrm{H}_{2} \mathrm{O}$, SPORL, DA, and FA were not very effective for this recalcitrant mixed sawdust. 
Table 1. Composition analysis of the pretreated sawdust.

\begin{tabular}{|c|c|c|c|c|c|c|c|c|}
\hline Pretreatment & $\begin{array}{c}\text { Solid } \\
\text { recovery } \\
(w \mathrm{t} \%)\end{array}$ & $\begin{array}{c}\text { Cellulose } \\
(\mathbf{w t} \%)\end{array}$ & $\begin{array}{c}\text { Cellulose } \\
\text { recovery } \\
(\mathbf{w t} \%)\end{array}$ & $\begin{array}{c}\text { Hemicellulose } \\
(\mathbf{w t} \%)\end{array}$ & $\begin{array}{c}\text { Hemicellulose } \\
\text { removal } \\
(\mathbf{w t} \%)\end{array}$ & Lignin (wt\%) & $\begin{array}{l}\text { Lignin } \\
\text { removal } \\
(w t \%)\end{array}$ & $\operatorname{Crl}(\%)$ \\
\hline Raw & 100.0 & 41.8 & - & 29.8 & - & 28.5 & - & 22.4 \\
\hline SPORL & 75.8 & 55.4 & 100.5 & 18.8 & 65.9 & 25.8 & 53.1 & 37.8 \\
\hline DA & 77.5 & 44.4 & 82.3 & 10.0 & 81.4 & 45.6 & 15.3 & 27.5 \\
\hline FA & 65.0 & 61.2 & 95.2 & 2.1 & 96.7 & 36.8 & 42.8 & 30.0 \\
\hline $\mathrm{EtOH} / \mathrm{H}_{2} \mathrm{O}$ & 61.9 & 50.2 & 74.5 & 27.4 & 59.4 & 22.3 & 66.9 & 38.8 \\
\hline $\begin{array}{c}\mathrm{EtOH} / \mathrm{H}_{2} \mathrm{O} / \mathrm{H} \\
{ }_{2} \mathrm{SO}_{4} \\
\end{array}$ & 44.6 & 71.8 & 76.7 & 11.3 & 88.0 & 16.9 & 81.9 & 55.6 \\
\hline
\end{tabular}

\section{Acknowledgements}

The authors would like to acknowledge the financial support of Qingchuang Science and Technology Program of Shandong Province University (2019KJD004), and SDUST Research Fund (2018YQJH102). 


\section{References}

1. Sikarwar, V. S.; Zhao, M.; Clough, P.; Yao, J.; Zhong, X.; Memon, M. Z.; Shah, N.; Anthony, E. J.; Fennell, P. S. Energy Environ. Sci. 2016, 9, 2939-2977.

2. Wang, Z.; Hou, X.; Sun, J.; Li, M.; Chen, Z.; Gao, Z. Bioresource. Technol. 2018, 254, 145-150.

3. Heinimö, J.; Pakarinen, V.; Ojanen, V.; Kässi, T. International bioenergy trade-scenario study on international biomass market in 2020. Lappeenranta University of Technology, Finland, 2007.

4. Shaheen, T. I.; Emam, H. E. Int. J. Biol. Macromol. 2018, 107, 1599-1606.

5. Asada, C.; Sasaki, C.; Nakamura, Y. Waste Biomass Valorization. 2019, 10, 433-439.

6. Ruiz Cuilty, K.; Ballinas Casarrubias, L.; Rodríguez de San Miguel, E.; de Gyves, J.; Robles Venzor, J. C.; González Sánchez, G. Biomass Bioenergy. 2018, 111, 114-124.

7. Zhao, X.; Zhang, L.; Liu, D. Biofuels, Bioprod. Bioref. 2012, 6, 465-482.

8. Sun, Y.; Cheng ,J. Bioresource. Technol. 2002, 83, 1-11.

9. Zhao, X.; Zhang, L.; Liu, D. Biofuels, Bioprod. Bioref. 2012, 6, 561-579.

10. Zabed, H.; Sahu, J. N.; Suely, A.; Boyce, A. N.; Faruq, G. Renewable Sustainable Energy Rev. 2017, $71,475-501$.

11.Zhang, J.; Zhou, H.; Liu, D.; Zhao, X., in Lignocellulosic Biomass to Liquid Biofuels, A. Yousuf, D. Pirozzi, F. Sannino, Academic Press, 2020, 17-65.

12. Dziekonska Kubczak, U.; Berlowska, J.; Dziugan, P.; Patelski, P.; Balcerek, M.; Pielech Przybylska, K.; Czyzowska, A.; Domanski, J. BioResources. 2018, 13, 6970-6984.

13. Jin, S.; Zhang, G.; Zhang, P.; Li, F.; Fan, S.; Li, J. Bioresource. Technol. 2016, 205, 34-39.

14. Lai, C.; Yang, B.; He, J.; Huang, C.; Li, X.; Song, X.; Yong, Q. Bioresource. Technol. 2018, 269, 1824.

15. Zhu, J. Y.; Pan, X. J.; Wang, G. S.; Gleisner, R. Bioresource. Technol. 2009, 100, 2411-2418.

16. Zhou, H.; Zhu, J. Y.; Luo, X.; Leu, S.-Y.; Wu, X.; Gleisner, R.; Dien, B. S.; Hector, R. E.; Yang, D.; Qiu, X.; Horn, E.; Negron, J. Ind. Eng. Chem. Res. 2013, 52, 16057-16065.

17. Zhou, H.; Zhu, J. Y.; Gleisner, R.; Qiu, X.; Horn, E.; Negrón, J. Holzforschung. 2016, 70, 21-30.

18. Chen, H.; Zhao, J.; Hu, T.; Zhao, X.; Liu, D. Appl. Energ. 2015, 150, 224-232.

19. López, F.; Pérez, A.; García, J. C.; Feria, M. J.; García, M. M.; Fernández, M. Chem. Eng. J. 2011, $166,22-29$.

20. Salapa, I.; Katsimpouras, C.; Topakas, E.; Sidiras, D. Biomass Bioenergy. 2017, 100, 10-16.

21. Li, Z. Q.; Jiang, Z. H.; Fei, B. H.; Pan, X. J.; Cai, Z. Y.; Liu, X. E.; Yu ,Y. BioResources. 2012, 7, 3452-3462.

22. Zhao, X.; Liu, D. Bioresource. Technol. 2012, 117, 25-32.

23. Mou, H.; Wu, S. Cellulose. 2017, 24, 85-94.

24. Wood, T. M.; Bhat, K. M. Method. Enzymol. 1988, 160, 87-112.

25.Zhou, H.; Zhu, J. Y.; Gleisner, R.; Qiu, X.; Horn, E.; Sukumaran, R. K. Frontiers in Energy Research. 2015, 3, 16.

26. Liang, Y.; Duan, W.; An X.; Qiao, Y.; Tian, Y.; Zhou, H. Bioresource. Technol. 2020, 310, 123389.

27. Shi, X.; Zhao, B.; Zhou, H.; Tian, Y.; Qiao, Y.; Ji, B. ChemistrySelect. 2019, 4, 7844-7850.

28. Jin, S.; Zhang, G.; Zhang, P.; Li, F.; Wang, S.; Fan, S.; Zhou, S. Bioresource. Technol. 2016, 221, 2630.

29. Pan, X.; Xie, D.; Yu, R. W.; Saddler, J. N. Biotechnol. Bioeng. 2008, 101, 39-48.

30. Cui, X.; Zhao, X.; Zeng, J.; Loh, S. K.; Choo, Y. M.; Liu, D. Bioresource. Technol. 2014, 166, 584591. 
31. Sindhu, R.; Binod, P.; Satyanagalakshmi, K.; Janu, K. U.; Sajna, K. V.; Kurien, N.; Sukumaran, R. K.; Pandey, A. Appl. Biochem. Biotech. 2010, 162, 2313-2323.

32. Pan X.; Xie D.; Gilkes N.; Gregg D. J.; Saddler J. N., in Twenty-Sixth Symposium on Biotechnology for Fuels and Chemicals, B. H. Davison, B. R. Evans, M. Finkelstein, J. D. McMillan, Humana Press, Totowa, NJ, 2005, 1069-1079.

33. Pielhop, T.; Larrazábal, G. O.; Studer, M. H.; Brethauer, S.; Seidel, C.-M.; von Rohr, P. R. Green Chem. 2015, 17, 3521-3532.

34. Hsu, T. C.; Guo, G. L.; Chen, W. H.; Hwang, W. S. Bioresource. Technol. 2010, 101, 4907-4913.

35. Huijgen, W. J. J.; Smit, A. T.; Reith, J. H.; Uil, H. d. J. Chem. Technol. Biotechnol. 2011, 86, 14281438.

36.Zhang, H.; Zhang, S.; Yuan, H.; Lyu, G.; Xie, J. Bioresource. Technol. 2018, 249, 395-401.

37. Valenzuela, R.; Priebe, X.; Troncoso, E.; Ortega, I.; Parra, C.; Freer, J. Ind. Crop. Prod. 2016, 86, 7986.

38. Sannigrahi, P.; Kim, D. H.; Jung, S.; Ragauskas, A. Energy Environ. Sci. 2011, 4, 1306-1310.

39. Li, H.-Y.; Chen, X.; Wang, C.-Z.; Sun, S.-N.; Sun, R.-C. Biotechnol. Biofuels. 2016, 9, 166.

40. Li, W.; Liu, Q.; Ma, Q.; Zhang, T.; Ma, L.; Jameel, H.; Chang, H.-m. Bioresource. Technol. 2016, 219 , 753-756.

41. Ebrahimi, M.; Caparanga, A. R.; Ordono, E. E.; Villaflores O. B. Renew. Energ. 2017, 109, 41-48.

42. He, Y.; Pang, Y.; Liu, Y.; Li X.; Wang, K. Energ. Fuel. 2008, 22, 2775-2781.

43. Xiao, B.; Sun, X. F.; Sun, R. Polym. Degrad. Stabil. 2001, 74, 307-319. 